\title{
IGFBP5 wt Allele
}

National Cancer Institute

\section{Source}

National Cancer Institute. IGFBP5 wt Allele. NCI Thesaurus. Code C52285.

Human IGFBP5 wild-type allele is located within 2q33-q36 and is approximately $23 \mathrm{~kb}$ in length. This allele, which encodes insulin-like growth factor-binding protein 5 , plays a role in the regulation of insulin-like growth factor and in protein transport in the circulatory system. 